\title{
"Free libraries for the free people": how mass-literature "shadow" libraries circumvent digital barriers and redefine legality in contemporary Russia
}

\author{
Bella Ostromooukhova
}

\begin{abstract}
Shadow mass-literature online libraries in Russia developed during the early Post-Soviet years. They are a phenomenon rooted in both the practice of circumventing constraints caused by state censorship, and a book production process of insufficient quality. Since the fall of the USSR, Russian legislation has aligned itself with international standards, adopting their strictest instantiation. In 2013, an "anti-piracy" legislation made "information intermediaries" responsible for illegal content, introduced an "eternal" blocking of sites, made pre-trial negotiations more difficult. Successive amendments have sought to respond to the circumvention tactics developed by shadow libraries. In this context, for a library which is not part of the book market, remaining in the legal realm means freezing its own content or becoming a self-publishing platform. Libraries that become illegal have to ensure the sustainability and growth of their collections by multiplying their dissemination means, to provide personal security to the administrators through a "safe" geographical location or strict anonymity, and to guarantee an access to their collections on the Russian Federation territory through inventive circumvention techniques. They leave the public struggle against state and industry regulation of the Internet to the digital rights advocates, and promote a particular vision of "freedom" anchored in the mastery of technical tools and in uncensored cultural practices.
\end{abstract}

Key words: shadow library, Russia, censorship, “anti-piracy” law, Internet freedom 


\section{Introduction}

Maksim Moshkov, the administrator of lib.ru, one of the oldest online archives of literary texts in Russian, described in following terms the purpose of his library in the early 2000s:

It was a "collect all the books in the world" system. [The principle was that] some readers digitized and sent texts to me, others read and revised them, and if we could make it all happen with automatic scripts and converters, that would be wonderful. We would have a world library with all the books in it. In about 2000 or 2002 I still thought that the project would end this way, that we just needed to be patient, grow up, endure... ${ }^{1}$

This idea of the Internet as enabling collective creation of a "universal library", which would allow access to worldwide knowledge for everyone, has emerged since its very first years of existence (Kruk, 1999). This idea was the basis of the utopia that this new communication tool would transcend the authority of states and their influential political and economic groups (Barlow, 1996; Turner, 2006). However, the idea of collecting, conserving and redistributing intellectual assets soon faced the commercial interests of their traditional producers, protected by the states that seek to regain control over their national cyberspace (Lessig, 2006; Deibert et al., 2010; Morozov, 2012). Intellectual property legislation has been tightening in several countries since the 1990s, and since the late 1990s it has also included digital formats and uses (Samuelson, 2003). Text archives - alongside libraries distributing music or videos - have had to juggle with laws and its implementation in order to remain (or not) in the legal realm. Cultural industries have, since the mid-2000s, integrated the production and distribution of e-books; however, the free circulation of texts in electronic

\footnotetext{
${ }^{1}$ Interview with Maksim Moshkov, 4 July 2019.
} 
format has become the focus of political and economic struggles, with a number of "shadow"2 libraries thriving on the Internet.

The idea of free access to knowledge as a fundamental right is promoted by actors who are sometimes grouped under the heterogeneous label "hackers". The hacker figure, emerged in the American Computer Science labs in the 1960s, rapidly diversified, encompassing a multitude of practices, spheres of action, and cultural domains involving various political grammars, from anarchism to libertarianism (Maxigas, 2012), from a figure of capitalist entrepreneur to a para-Marxist utopic character (Dagiral, 2008, p. 495), sometimes combining several political stances (Coleman, 2013). What these heterogeneous characters have in common is primarily an "action repertoire" (Van Laer and Aelst, 2010): they bypass or destroy a material or symbolic fence in order to appropriate the contents of a "black box". This action can be defined as "breaking to repair, hooking to disseminate, transgressing to augment", as well as a "reaction to a certain mode of commercial exchanges, and to the practices of control that result from it" (Bacot and Canonne, 2019, p.10). They are also united by what De Filippi and Dulong de Rosnay call "technical ethic". Their mastery of the technical means of disseminating knowledge and circumventing constraints serves to distribute power and create hierarchies within hacker communities (De Filippi and Dulong de Rosnay, 2014). Hackers erase or minimize the barriers created by intellectual property rights by "cleverly reformat(ting) copyright law to prioritize access, distribution and circulation", thus short-circuiting "the traditional uses of copyright: the right to exclude and control" (Coleman, 2013, p.15). While some of these movements, such as Anonymous, Wiki-Leaks or

\footnotetext{
${ }^{2}$ The term "pirate", although frequent in common speech, has multiple connotations that are often instrumentalized by the actors. Stigmatizing "piracy" highlights the violent or even "terrorist" aspect of their actions and therefore justifies their banishment. However, "pirates" often refer to themselves as such, because of the idea of freedom and power attached to this figure which can therefore play a liberating role (Keucheyan, 2008; Hayat and PaloqueBergès, 2014). In order to distance myself from these additional meanings, I will call our object of study, following the footsteps of Joe Karaganis (2018), the "shadow libraries", using the word "pirate" or "piracy" only when it is used by the actors themselves.
} 
data-activist practices (Milano, 2017), clearly articulate a critical political agenda, others pursue it only implicitly, while devoting themselves to artistic creation, leisure or crime (Turovsky, 2019).

The tightening of intellectual property laws, as well as other attempts by states and large corporations to regulate the Internet, has also spawned an ecosystem of digital freedom advocates, which only partly intersects with the hacker universe.

In this article, I examine the Russian-language mass-literature shadow libraries as it intersects with the nebula of "hackers" on the one hand, and with the ecosystem of "digital freedom" advocates (Pirate party, open access movements, web and communications professionals) on the other hand. Their evolution is analyzed through some emblematic casestudies from each period: lib.ru, also called "Moshkov Library", whose popularity peaked in the late 1990s and early 2000s; Librusec, which appeared in 2007 and reached its peak in the mid-2010's ${ }^{3}$; Flibusta, created by disillusioned members of the Librusec community when the service introduced a paid subscription system in $2009^{4}$; and Maxima library, which appeared in 2015 as a "legal" resource and was almost immediately pushed into the shadows. On the basis of these case studies, I show how Russian-speaking literary shadow libraries emerge and mutate, within national and global context of bypassing digital constraints. The aim of the article is also to question the nexus between struggles for "free" access to content and against "censorship".

The phenomenon of shadow libraries is often considered from an ethical and economic standpoint, heavily influenced by political positionings: it is described either as "theft" that hinders the book industry (Waldfogel, 2018), as a lubricant that helps the

\footnotetext{
${ }^{3}$ According to its administrator, it was the most visited Russian language website in 20122013.

${ }^{4}$ Flibusta is currently one of the most active shadow archives, navigating legislative loopholes and introducing new technical means to circumvent the prohibitions.
} 
publishing ecosystem work ${ }^{5}$ or as a means to rectify the biases and counter the inequalities generated by the book industry (Karaganis, 2018). In this article, I propose to consider shadow libraries as actors that perform an "infrastructural function as they help to structure, shape, model, enable or constrain our 'being together' on and with the Internet" (Musiani, 2018, p. 161). These libraries shape and constrain the relationship between the Internet user and the text, by establishing a direct link between these two entities, with or without the agreement of the author and the rightsholder. These databases bring together communities that discuss and share values, know-how, implicit knowledge, humour, and specific slang. Being at the crossroads of several political, commercial and legal agendas, they raise controversies that contribute to questioning, destabilizing and re-stabilizing legal norms and trade balances, at national and international level.

The study is based on a qualitative survey that includes semi-structured interviews with different actors. I interviewed lawyers who participated in the elaboration of "antipiracy" legislation and others who defend shadow libraries, as well as members of NGOs involved in negotiating the limits of legality (Roskomsvoboda, Wikimedia.ru and Association of Web Publishers). The interviews took place in Moscow in February-March and June 2019, and they enable me to retrace the terms of the controversy surrounding the recent tightening of the legislation. Interviews with lib.ru (June 2019) and Librusec (July 2020) administrators, supplemented by a study of online discussions within the "communities" on library forums and personal blogs, conducted in 2019-2021, offers a novel perspective on circumvention strategies and their meaning for these actors.

\footnotetext{
${ }^{5}$ For instance, the science fiction writer Leo Kaganov considers that "free distribution can be very useful for the authors, especially young and unknown ones", since it increases their professional potential. See Leo Kaganov, "There are benefits to pirate libraries" at https://web.archive.org/web/20090730000859/http://www.slon.ru/articles/59387, accessed on 1 June 2020.
} 


\section{The emergence of a legal market: between global logics and national}

\section{particularities}

Shadow libraries must first be placed in the context of Soviet and post-Soviet history. The USSR had its own rules and customs, different from those of the countries that had subscribed to the Berne Copyright Convention (1886). The Soviet state proclaimed "freedom of translation" as early as the 1920s, thus making the publication of foreign authors in the USSR possible without needing their permission or the acquisition of rights. USSR acceded to the Universal Copyright Convention in 1973. However, a certain degree of freedom towards foreign rightsholders remained, even a few years after the fall of the USSR in 1991 - until the end of the 1990s and sometimes even beyond.

For works created on Soviet soil, intellectual property was first defined by a decree of the Central Executive Committee and the People's Commissariat in 1928, before being included in the "Foundations of Civil Legislation of the Soviet Union and the Union republics" of 1961. The length of the protection of rights was shorter than elsewhere (15 years after the author's death, extended to 25 years after the signing of the Universal Copyright Convention), and the range of "free of charge" uses was considerable, in order to make officially selected and approved works as widely accessible as possible. But copyright was also an indirect instrument of censorship, because editorial approval meant selection of works in accordance with the political purposes defined by the CPSU (Elst, 2005, p. 28).

Samizdat, as a not-for-profit craft production of texts (monographs, antologies, leaflets, periodicals) banned by Soviet censors or not recognised by publishing houses, circumventing both copyright and censorship issues, was not illegal as long as the works produced and distributed outside of official channels were not sold (Elst, 2005, p.34). In practice, however, informal uncensored text typing and distribution was still considered a 
criminal activity contributing to the dissemination of "anti-Soviet" politically harmful content, and individuals responsible for Samizdat production, distribution or consumption were severely repressed. On the other hand, informal distribution of published books on the black market, that proliferated in the 1970s-1980s, was prohibited as an illegal commercial activity, but still tolerated by the Soviet state as a response to the shortcomings of the planned economy (Thiesse and Shmatko, 1999, p.77).

Moreover, since books played an essential role in the Soviet value system, $68 \%$ of households in large cities bought books on the black market in order to cope with the shortage of fashionable literature (Stemakh, 2001, p. 146). Maksim Moshkov describes digitization and the first exchanges of texts in the 1990s as a way of quenching one's "thirst for reading" grounded in the shortage of the late socialist period:

We are used to the fact that if a book is good, you cannot buy it in a bookshop, it is sold out. And in the library, you have to queue and even then, you do not know if you will get it. This is why we were all used to running after books. You challenge yourself to find something specific, you stand in queues, you ask your friends... And then you come to work and see that the book you are missing is right there. And you're not in a library where you have to return it, or in a shop where it's never available, or with a speculator who would sell it to you four times the normal price... Here is the file - you may just take it, copy it to your computer, and that is it $^{6}$.

The practices developed after the economic liberalization brought about by the fall of the Soviet Union, in 1991, were thus rooted in the habits of a late Soviet man in short supply of reading material. The habitus of well-cultured Soviet and Post-Soviet individuals included the production, the consumption and the sharing of published and self-printed works regardless of their legal status. The use of digital technology as convenient means of preserving and sharing texts, which coincided with the advent of the market economy, was in

\footnotetext{
${ }^{6}$ Interview with Maksim Moshkov, 4 July 2019.
} 
line with already existing practices, which remained unchanged in the first post-Soviet years (Bodó in Karaganis, 2018). Technical breakthroughs such as the appearance and growing accessibility of personal computers, copy machines and scanners, but also the introduction in 1993 and rapid proliferation in Russia of the FineReader program, allowing to convert photocopied text into a text file, encouraged book lovers to digitize and collect their favourite literature. Maksim Moshkov mentions the existence of digitized literary materials as early as the 1970 s as well as their presence on shared workstations in scientific research institutes. Their diffusion within the scientific community initially happened offline, by copying files from other accounts on one's personal computer space, or by exchanging them with the help of floppy disks:

I started collecting a small group of texts first. Then I was travelling, I searched for texts, copied them from other computers and put them all together. It would all fit on a floppy disk. When someone wanted to share a text with me, when I went to visit someone, or when I travelled for work, I discovered other people's books. I would say: see what I can give you in exchange! It was a current sharing practice ${ }^{7}$.

Early data exchange systems offered an additional sharing mechanism. Prior to the Internet's rise to prominence, data exchange systems such as the Bulletin board system (BBS) and FIDOnet appeared in the academic community and quickly gained widespread adoption. The first Russian FIDOnet connection nodes were established at the end of 1990 in Novosibirsk and Chelyabinsk and at the beginning of 1991 in Moscow and St. Petersburg. FIDOnet quickly grew in Russia and was highly popular in the 1990s while Internet expansion within the Russian Federation remained limited (Savickaja, 2011). Driven by the overall spirit of almost free access and sharing, FIDOnet users began exchanging literary texts

\footnotetext{
${ }^{7}$ Ibid.
} 
and digital libraries with the mission of collecting and consolidating the texts "sprung up by the dozens" (Bodó, 2018, p. 36).

Moshkov underlines the absence of the very notion of copyright in the minds of these text collectors: "Nobody knew what copyright was, what right was. We only knew what was ftp, http, server, browser, programs, and editor. We did not know such words as copyright ${ }^{8}$ ". Conversely, "publishers did not know what Internet was, writers did not know that there were also books in electronic formats, they just ignore all about their existence ${ }^{9 "}$. In the early 1990s, the Russian state had more urgent issues to deal with and turned a blind eye on copyright-ignoring practices as long as they satisfied the population's need for entertainment and prevented social unrest (Kirya, 2011).

However, by the mid-1990s, public discussions about the enforceability of copyright for electronic reproductions of texts multiplied (Bodó in Karaganis, 2018). The Russian copyright legislation and its implementation were gradually being aligned with world standards, through negotiations by rightsholders' representatives on the one hand and the Internet industry professionals and digital freedom associations on the other. Copyright terms of the new Russian state were first established by Law No. 5351-1 about Intellectual Property and Related Rights, adopted in 1993, which aimed to adapt copyright to the emerging market economy (Elst, 2005, p. 370). Copyright duration was extended to 50 years after the author's death, which corresponded to the Berne Copyright Convention joined by Russia in 1995. The law also excluded several cases of free use provided by the Soviet legislation, recognized previously non-existent connected rights, and enabled the appearance of organizations responsible for the collective management of intellectual property rights (IPRs).

At around the same time, the Russian government began negotiations to join the World Trade Organization (WTO) which concluded only in 2012. On this occasion, American

\footnotetext{
${ }^{8}$ Ibid.

${ }^{9}$ Ibid.
} 
companies, such as Microsoft, the Motion Picture Association of America (MPAA) and the Recording Industry Association of America (RIAA), demanded a firmer commitment from Russia in terms of IPRs protection. In response, copyright term was extended, in 2004, to 70 years, thus aligning itself with the US 1998 Copyright Term Extension Act (Alekseeva et al., 2013, p.69). At the same moment, the Law on the Intellectual Property and Related Rights was amended to include digital uses of works in copyright protection (Rassolov, 2016), in accordance with the American 1998 Digital Millennium Copyright Act (DMCA). However, this law was implemented only on a sporadic basis, in particular due to the lack of real means of pressure and to confusion between different legislations.

In 2006, the Part IV (concerning Intellectual Property and Related Rights) of the Civil Code of the Russian Federation, under elaboration since the 1990s, was adopted. Immediately after it entered into force on 1 January 2008, president Medvedev ordered it to be revised. On the one hand, it had to include standards set by the Agreement on Trade-Related Aspects of Intellectual Property Rights (TRIPS) (Alekseeva et al., 2013, p.62). On the other hand, it echoed the debates among Internet professionals, such as the Russian Association of Electronic Communications (RAEK), founded in 2006, and Internet freedom associations like Wikimedia.ru and the Association of Web Publishers ${ }^{10}$, that tried to create a simplified mechanism for interaction between rightsholders and information intermediaries, and to legalize open licenses in Russia (Alekseeva et al., 2013, p.72). President Medvedev stood by the side of these experts: in 2008, he called to "limit the responsibility of information intermediaries for content uploaded by users" (Zasurskij, 2016, p.54).

However, the state policy changed abruptly in 2012, with Putin's return to the presidency. His new mandate was characterized, from its inception, by approving legislative initiatives aiming at intensifying state control over the national Internet (Soldatov and

\footnotetext{
${ }^{10}$ This association, created in 2010, was co-founded by the president of Wikimedia Ru, and dedicates to promote the open access.
} 
Borogan, 2016). One of his first initiatives was the 2012 Federal Law No. 139, known as "black lists law". This law introduced a listing of websites with "illegal" content (i.e., providing information on drugs, child pornography, and suicide or falling under the vague category of "extremism"), to be blocked by Internet Service Providers (ISPs). The blacklist is kept by the Federal Agency for Supervision of Mass Communications (Roskomnadzor). A year later, in 2013, when other Duma deputies submitted a bill designed to apply the same mechanism to copyright-infringing libraries, President Putin took clearly the side of the rightsholders, and the Duma approved Federal Law No. 187, also called by its critics "antipiracy law", "the law against Internet" or "the Russian SOPA ${ }^{11 " . ~ I n d e e d, ~ t h e ~ l a w ~ e c h o e s ~ t h e ~}$ 2011 US Stop Online Piracy ACT (SOPA) and Protect Intellectual Property Act (PIPA) bills, which also "aimed the use of state power to harness the platform providers to enforce the interests of the copyright industries" (Nowak, 2016, p.178). But if the outcry raised by SOPAPIPA in American society has caused American legislators to back down (Herman, 2012, p.215-216), the Russian government has proved itself resistant to the mobilizations against the “anti-piracy law”, which were nonetheless numerous (Zasursky, 2016, p.62-63). Critics drew a parallel between the "blacklist law" and the "anti-piracy law", given the similarity of the mechanisms they put in place and the actors involved. This created a convergence of struggles against these two distinct issues, becoming a common struggle for a "free Runet" ${ }^{12}$. The law was adopted and is reinforced ever since, despite a petition launched by the new digital rights defending organization Roskomsvoboda ${ }^{13}$, which collected 100000 signatures (Antipiratskij zakon, 2017, p. 47), despite reports from RAEK on the nuisance of this legislation for the Internet industry and for the rightsholders themselves, and despite protest actions by Russian

\footnotetext{
${ }^{11} \mathrm{https}$ ://roskomsvoboda.org/5773/, accessed 2 June 2020.

12 "Runet" is a contraction of "Russian Internet", and is often used to refer to the sphere of websites mainly visited by Russian-speaking users.

${ }^{13}$ A digital rights-defending organization created in 2012 by members of the Russian Pirate Party. Its name is a pastiche of Roskomnadzor, "Nadzor" (surveillance) being replaced by "Svoboda" (freedom).
} 
Internet actors, similar to those of the American platforms mobilized against SOPA (Alekseeva et al., 2013, p.81-85). Its first version only applied to media content, but established a unified legal protocol and gave "information intermediaries" (site administrators, hosting providers and ISPs) responsibility for the legality of the content.

Amendments which came into effect on May 1, 2015 extended copyright protection to all dematerialized works besides photography. They also made out-of-court settlements between the rightsholders and the website owners more complicated, and increased sanctions. The Moscow City Court now had the right to definitively and irrevocably block sites in case of multiple infringements.

The legislation continued to develop in an attempt to efficiently counter various circumvention tactics. Amendments that came into effect on October 1, 2017 were directed against the "mirrors" created by shadow libraries in order to bypass site blocking. Roskomnadzor received the right to block these "mirrors". The next step was to ban shadow libraries from search results and the social media. To this aim, a memorandum was signed in November 2018 with major Russian search engines, like Yandex, as well as with the major Russian social media VKontakte. Website blocking has led to the proliferation of devices to get around this constraint. In turn, these tools have become the target of legal actions. A law published in November 2017 forbade VPNs to allow access to blocked sites and gave Roskomnadzor the right to block those who refused to comply. By the end of the 2010s, shadow libraries turned to messengers (and particularly Telegram ${ }^{14}$ ) and mobile apps as an alternative media to distribute their content. New amendments are in preparation since April 2020 to make these media and their aggregators App Store and Google Play responsible for

\footnotetext{
14 "Roskomnadzor will look into the App Store", https://www.kommersant.ru/doc/4323827, accessed 15 June 2020.
} 
disseminating illegal content. Votes to make search engines, social networks, messaging and other applications legally responsible for "pirate" content are to take place in $2021^{15}$.

The state's commitment to support the copyright industries was unsurprising, given the political and economic context. After the chaotic effervescence which followed the economic liberalization (Thiesse and Shmatko, 1999), the young Russian book market became highly polarized, with the emergence, during the 2000s, of big editorial groups, such as AST and Eksmo, which merged in 2013. In 2019, the group's sales represented $25 \%$ of the total volume of the Russian book market (“Knizhnyj rynok Rossii”, 2020, p.18-19).

In the beginning of the 2000 s, when digital formats gradually became attractive for traditional publishers, online libraries formed a market, defining the boundaries between "legal" and "illegal" players. The limits of legality were defined, in particular, with a series of "piracy" lawsuits, which began in 2004 with cases brought against major libraries adelbaran.ru and lit.ru by $\mathrm{KM}$, an online company specialized in multimedia educational products. This company wanted to develop the idea of a paid and "legal" electronic library, by signing contracts with the major Russian publishers. These trials resulted in minor fines for the incriminated library managers, which were now labelled as "illegal". However, in July 2006, a translator had filed a lawsuit against KM online for unauthorized use of his translations and won the case, thus expelling this library, in turn, from the legal sphere.

Parallel to these lawsuits, in 2005, the company Litres, the first large online bookstore specialized in the sale of e-books, was set up. Its founders, who were also administrators of large shadow libraries, analysed the reasons for the commercial failure of KM online in order to create a more effective operating system. In addition, they used their technical know-how, since one of the founders was Dmitri Gribov, the developer of the FictionBook (FB2) e-book format, having since become the technical platform of Litres (Haritonov, 2016, p.24) and the

\footnotetext{
${ }^{15}$ https://sozd.duma.gov.ru/bill/386109-7, accessed on 5 September 2020.
} 
most popular on the Russian market. The founders also set up a communication system between the "illegal" libraries they run and the legal ones: Litres signed a contract with writers that gave it exclusive rights to sell e-books, after which their "pirate" versions were removed from shadow libraries who directed their readers to Litres ${ }^{16}$. The "legal" library was thus largely nurtured by shadow libraries, which continued to exist in parallel. In 2009, Litres' shares were bought by AST and Eksmo, becoming their agent on the e-book market. Litres thus passed "from the 'pirates' that use technologies to disrupt order" to "powerful commercial and governmental bodies who use it to consolidate power" (Tufekci, 2016, p. 75). Bookmate, another platform dedicated to online reading, more oriented towards international development, was created at around the same time and developed in parallel, establishing agreements with a wide range of publishing houses. Since January 2020, this service also collaborates with AST-Eksmo, Litres having lost its exclusive partner status.

The legal e-book market has therefore been monopolized by the largest publishing houses. In order to combat shadow libraries, they set up, in 2013, a special organization to monitor the new releases of their shareholders and to prosecute shadow libraries, called The Association for the Protection of Copyright on the Internet (ASAPI).

While this commercial landscape was taking shape, the state began to reinvest the publishing field, in an attempt to regain control over the production of a Russian cultural identity, based on "traditional family values", "patriotism", etc. Drawing on both laws restricting public discourse and publishing support measures that promote works contributing to its identity-building, the State has therefore launched a process in which the book industry has an important place, restoring Russia's "most reading nation" status (Ostromooukhova, 2019).

\footnotetext{
16 "The LitRes story: The rise of the most popular e-book format and the birth of a new Russian market", https://vc.ru/flood/7998-litres-history, accessed on 5 september 2020.
} 
Thus, shadow libraries developed in the early Post-Soviet years, rooted in the circumvention of material constraints caused by the fact that the book industry was illtargeted, not focusing on content that people wished to read. They were marked by the arrival of the Internet, linked with an academic milieu that was hoping to achieve its democratic dreams. These were also the years of the arrival of the market economy, when the state abruptly withdrew from the cultural sphere, while turning a blind eye to copyright issues in particular. In the 2000s, intellectual property legislation is beginning to take shape, and a legal market of online libraries is developing, initially in symbiosis with its shadow epigones, before being taken over by the majors of the national publishing industry. The latter, supported by President Putin and his government following their own control and identityproducing agenda, promoted 'anti-pirate' legislation. This legislation, which has been evolving since 2013, following technological developments and circumvention techniques used by a wide range of shadow libraries, which had to define their place in relation to the legal market.

\section{Between "shadow" and "light": the attempts of digital libraries to remain in the}

\section{legal realm}

Between 2004 and 2008, Moshkov had to choose, for lib.ru, between some form of legality or survival outside the legal framework; he opted for the first solution. His library's exponential growth phase was already over at that time. Adding content was indeed a collaborative process, but it was not automatically performed: users sent by email scanned books transformed into text files to the administrator, who sorted the messages and uploaded the texts online. When the flow of new texts became too important, Moshkov created a new library section, which he called "Samizdat" in reference to the Soviet self-publishing 
movement. It was dedicated to texts sent by their authors for a first online self-publication. Moshkov does not consider this part as "real literature" since it was not sanctioned by a publisher and could therefore do without a "gatekeeper"17. Hence, the Samizdat section was equipped with a program allowing the authors to upload the texts themselves, so it could grow without the intervention of the administrator, whose role was reduced to solving possible technical problems or rare setbacks with Roskomnadzor ${ }^{18}$. The library part, with published books, has been frozen since the late 2000s. It remains a "historical monument"19 which contains copyright-free works or texts whose owners have not notified their rights. The administrator justifies this change by a range of reasons.

The first reason is the centralized archive-building mechanism, which has its vulnerabilities: it is dependent on the amount of free time that the administrator can dedicate to the task. And since the mid-2000s, Moshkov had no longer space in his schedule for such a time-consuming activity. The second reason is due to the book-procuring paradigm change. The community that nurtured the lib.ru archive valued the handiwork of scanning books and converting them into text format. This process was considered as a valuable do-it-yourself practice per se. Since e-books produced by publishing houses became commonplace, scanning books became an outdated practice, and the community based on it progressively disintegrated. The flow of scanned works gradually diminished, stopping the library's growth. The third and last reason of the "museumization" of lib.ru is due to Moshkov's reluctance to choose between a "professional" and an "outlaw" status. As the legal field has been occupied by commercial structures, he sees no place in it for his archive, which he conceives as

\footnotetext{
${ }^{17}$ Interview with Moshkov, ibid.

${ }^{18}$ In the interview, Moshkov mentions texts that he had to remove from the Samizdat section on Roskomnadzor's orders, as part of campaigns against juvenile suicide or drug dealing. While emphasizing the absurdity of some of these requests, he stated that he had to comply with them in order to maintain library's legal status.

${ }^{19}$ This term is used by Moshkov. The structure and design of the site remain unchanged since the 1990s, which contributes to its patrimonialization. The texts are only available in .rtf format, uneasy to read from electronic devices such as tablets or telephones.
} 
“amateur by nature ${ }^{20 "}$. Moreover, this hobby provided him with a significant social capital. As a public figure of the Runet, he is a visible and easily traceable person "with a passport, an address a telephone number" 21 , which renders him vulnerable to possible repression.

At the same time, the Samizdat section continues to grow since the early 2000s. In addition to saving the administrator's time by putting the texts online independently, it also allows to circumvent the problem of copyright, or rather to relieve the administrator's responsibility in this regard. Moshkov notes that this section has become a kind of nursery for publishing houses, that regularly seek new authors there. Once authors are spotted and their work published, it becomes their responsibility to negotiate with the publishing house whether or not their work will be freely available in Moshkov's Library.

Thus, the significance of the library shifted: on the one hand, it remains a museum-like storage place for royalty-free classics; on the other hand, it is a self-publishing site, with its community of authors in search of an audience and a publisher, its internal operating rules ${ }^{22}$, and its code of conduct towards publishing houses, drawn up during the actual collaborations.

Until the mid-2010, some administrators still hoped to find a way to keep shadow libraries in the legal realm in order to put the collections permanently out of authorities' reach, but without success. The Maxima Library ${ }^{23}$, for example, first tried the tactic of "loyalty", which proved to be effective for Moshkov's Library. Its first page claims: "It is a free library for free people (...) We are working to ensure legal public access to works without infringing anyone's rights". Later, the administrators announced on the forum that they were forced to remove some books in order to maintain the possibility of offering free

\footnotetext{
${ }^{20}$ Internview with Moshkov, ibid.

${ }^{21}$ Ibid.

${ }^{22}$ The Samizdat community is federated around competitions in different literary genres and forums where texts are discussed.

${ }^{23}$ A library created in June 2013 on the basis of Librusek and Flibusta archives.
} 
access to the rest. Nevertheless, despite these efforts, in December 2016 the website was blocked. The library's representative on the forum librusec.ucoz announced it in a bitter way:

Because of some two lousy books by a certain Perelyagin, what have been on our site for ages, we are "blocked at the request of rights holders". But none of these book murderers read those books, it is not the rightsholders' business to read, their business is to prevent people from reading (...) The Library keeps working, of course, everybody knows the ways and methods of circumvention (well, maybe apart from the members of Roskompozor $\left.^{24}\right)^{25}$.

Henceforth pushed into the "shadows", this library must implement the circumvention strategies that the representative presents as common knowledge. This move out of the legal sphere is welcomed by the other forum users who, in their commentaries, sarcastically reverse the stigma: "welcome!", "at last, you are considered a serious library".

For its part, Librusec tried to remain legal in 2009, when it entered into an informal agreement with the recently created Litres. According to it, new releases would not be freely available during the first month after their publication. Ilya Larin, Librusec's administrator, justifies this agreement by the diverging objectives of these two libraries: "And it did not really bother me, because I am not really interested in recent literature as such. My idea is that what I have accumulated should not be lost" 26 . Librusec would therefore have occupied a different market niche. In any case, this allowed one of the administrators to announce on his page that "Librusec from a library becomes a store" 27 , a paying service. The subscription, which Larin later calls a "donation" 28 , amounted to about 10 dollars per month and had to be divided among the authors. This also led to a financial relationship with Litres:

\footnotetext{
${ }^{24}$ This term is a distortion of the name "Roskomnadzor", crossed with that of "pozor", shame. ${ }^{25} \mathrm{http}$ ://librusec.ucoz.de/forum/27-2818-103197-16-1482497381

${ }^{26}$ Interview with Larin, 14 July 2020.

27 http://lib.rus.ec/node/181009, accessed 16 July 2020.

28 Interview with Larin, ibid.
} 
We posted their advertisement (...) on the page of some books, and in addition to reading it on the Librusec you could click a button to buy the same book on Litres (...) And if we dragged new clients to them, they would pay a percentage from the purchase. Well, that is a normal scheme for cross-site settlements on the Internet.

This attempt to enter the legal digital book market by treating one of its Russian majors as a business partner was, however, badly received on both the "legal" and the "shadow" sides. Litres publicly denied this partnership, while some active members of the community considered it a betrayal and leaved Librusec to found the Flibusta library, which declared free of charge access as its core value. The commercial schemes conceived by Larin did not work and despite the "donations", the director of ASAPI continues to consider this resource a "vicious pirate" 29 . The decision concerning its "eternal blocking" on the territory of the Russian Federation was taken by the Moscow City Court in August 2016.

Flibusta's administrators looked instead for technical solutions to avoid being labelled as "outlaws". Among the means under consideration was, for instance, decentralized book storage. This solution was discussed by "Stiver", one of Flibusta's administrators, in December 2009. By launching this discussion on the forum, he wished to find a way to make the downloading of books definitely legal, which he considers to be a more sustainable means than the circumvention of incessant legal barriers:

FreeNet is based on hiding the IP addresses of participants. And I want an open scheme [that would be] invulnerable to copyrightists at the same time. It is very easy to forbid FreeNet, but they can never forbid quoting.

\footnotetext{
${ }^{29}$ Interview with Riabyko, 21 June 2019.
} 
The principle would be to separate a book into several files whose size would not exceed the legal limits of a quotation, and to distribute these files among the library users. And each file would be provided with a link to the following segment. However, the community criticized this method as too unstable (if one link in the chain breaks, the reconstruction of the entire work will be impossible) and too complex to implement.

While shadow libraries could maintain close links with the official market until the early 2010's, my case studies show that the application of the "anti-piracy law" definitely outcasts these grey areas and radicalizes the legal vs. illegal dichotomy. Thus, most shadow archives, blocked by Roskomnadzor before the end of 2016, needed to forge tools of digital resistance.

\section{Shadow libraries' circumvention tactics}

Russian shadow libraries developed survival strategies according to three objectives. The first one is ensuring the sustainability and growth of the collection, which in turn depends on the vitality of the community that makes it flourish. The second one is providing personal security to the administrators, who may bear legal responsibility for the alleged fraud. Finally, these libraries are seeking to guarantee an access to their collections on the Russian Federation territory.

Today's shadow libraries are "communities" that bring together readers and administrators (Bodó, 2018). Unlike Moshkov's Library, Librusec, Flibusta and Maxima Library operate as Wiki-like libraries, where texts and annotations on authors and works are uploaded and corrected by the users themselves. Their range of possible actions depend on their seniority, "abilities" (such as coding skills) and "merits" (e.g. technical problems resolved, number of books uploaded). But the possibility for any logged member to upload 
and modify content remains a basic principle for shadow libraries. This may have allowed senior administrators - who are usually very few in number - to disavow themselves in the hypothetical case of any legal liability: they could say that they were not responsible for usergenerated content ${ }^{30}$. This argument, though, is no longer valid since the introduction of the notion of "information intermediaries" by the "anti-piracy" legislation.

On the other hand, this collective work ensures the possibility of exponential growth of collections. Ilya Larin, a programmer by profession who shares the ethics of free software exchange, has made the source code of his library freely available ${ }^{31}$. As Coleman noticed, this practice of code sharing is deeply rooted in a worldview where "code is speech", typical of hacker culture, and thus freedom of speech and code sharing are intrinsically connected (Coleman, 2012, p.9). The interview I conducted with Larin shows that he relies on both code and text sharing to guarantee the survival of the ecosystem:

They (Flibusta) borrowed my site engine, cloned my archive. A lot of libraries once took the Librusec site engine. Since then, they all have developed in different directions. But there is constant cross-pollination: someone has a new book, there is a mass of librarians that work simultaneously on several websites and drag and drop books. It is now a dense community that is much more sustainable. If Librusec disappears tomorrow, well, nothing will happen.

This "cross-pollination" preserves collections by multiplying the media and the means of dissemination, thanks to the members of these communities who share particular knowhow or having access to specific libraries. For instance, Larin argues that, when a large volume of archives is to be downloaded (such as all the updates of a month or a year), it is "more convenient to download them from a torrent, and there are volunteers who regularly

\footnotetext{
${ }^{30}$ Interview with Larin in livejournal, https://ya-parazit.livejournal.com/227533.html, accessed 16 July 2020.

${ }^{31}$ https://github.com/larin/librusec, accessed 1 July 2020.
} 
pull these updates from the Librusec and hand them out through the torrents". Some shadow libraries have their own torrents. Major torrent aggregators also distribute these archives and their updates. Torrents allow users to download the main archives in their entirety onto their computers, accompanied by a program that transforms the archive into a database for convenient use. Once the full database is installed on the computer, the user may download its monthly or annual updates. Comments on the torrent aggregators show that these distributions are the work of a small number of volunteers and that some users take over and distribute the uploaded archives through their own channels. Thus, the library's collection is replicated many times and kept not only online, but also offline. Its ability to be restored anytime makes its total disappearance impossible.

The server on which the main collection is stored is also of great importance for the security of the library. The legislation of the country where it is located must be sufficiently tolerant of copyright infringements. On the forums, the administrators exchange comments on "good" and "bad" locations. Larin states in the interview that there is a balance to be found between various types of censorship. Hosted in the Netherlands, a country perceived by the respondent as tolerant of pirate sites, Librusec had been attacked for "child pornography" because of an old sex education manual, and had to find a hosting in another country. Thus, the administrators of the shadow libraries use the possibilities offered by the global aspect of the Internet, moving the servers according to local affinities.

Additional security is provided by the choice of anti-abuse hosts. Their services are more expensive, but they are a bulwark against possible complaints from rightsholders that an ordinary host would satisfy without going into detail.

Another task for library administrators is to ensure their personal safekeeping. Indeed, "anti-pirate" legislation makes them responsible for the illegal content of the sites they maintain. Two tactics co-exist: first, the use of a geographical remote location that guarantees 
immunity; second, the strictest anonymity which does not permit to establish a link between a physical person and his virtual double. The geography of immunity does not coincide with the borders of Russia. Rather, it is defined by the interest of local authorities and industry in the piracy of books, most of which are Russian-speaking.

An example of the first tactic is Larin, who has been living in Ecuador since the beginning of 2000s. This location allows him not to hide his identity, which he uses in particular on social networks (Livejournal, Facebook) and in public interviews. During my interview with him, he stresses the ineffectiveness of court decisions in his country of residence:

- Litres brought a lawsuit against me, even in Ecuador. I think they even won, but it did not affect me in any way. The specificity of Latin America is that when one gringo sues another, it does not mean that they are somehow concerned.

- Can they charge you with a fine?

- They can charge me, yes. But they cannot force me to pay it. Besides, court decided that the Librusec domain should somehow be taken away from me, and that should kill the library. And it has been like that for two years now. However, it works, I renew it every year. Well, that is Ecuador ${ }^{32}$.

The word "gringo" underlines his status as a foreigner who is considered detached from local concerns. However, he feels distant from the Russian context too:

I have never seen them (people from Litres) alive; they are some people in a faraway Moscow on another continent who are doing their business. Well, great for them ${ }^{33}$.

\footnotetext{
${ }^{32}$ Interview with Larin, ibid.

${ }^{33}$ Ibid.
} 
His posture as a person who is ultimately free of geographical constraints makes him impervious to possible prosecution. We can note the difference with WikiLeaks founder Julian Assange who also saw in Ecuador (or at least in its London embassy) a safe harbour where he could escape rape charges by the Swedish police, and possible extradition to the US to face trial for leaking confidential government documents. The asylum granted to Assange was the result of an "anti-imperialist" stance by Rafael Correa, President of Ecuador, in 2012. Assange was handed over to the British police by his successor, Lenin Moreno, anxious to distance himself from his predecessor. Larin, for his part, underlines the apolitical nature of his choice of residence, made in 2000 , i.e., well before the creation of Librusec, "due to its pleasant climate". If the public figure of Assange was meaningful for Ecuador's foreign policy, Larin draws its strength precisely from its total insignificance in the local context. His example is taken by administrators of other libraries as the reason why they cannot afford to reveal their identity.

One of Flibusta's senior directors, who calls himself Stiver, supposedly lives in Germany. However, in November 2014 he related on the library's forum his confrontation with local law enforcement authorities, without naming the country where the conflict took place:

As some of you know, I have been under investigation for the last two years or so. The same nationally acclaimed publishing house filed a complaint against me, accusing me of all sorts of sins: from illegal reading to running an international crime syndicate. And of the related shadow enrichment, of course.

The police forces collected available information on me, searched my place of residence and work and seized my laptop. Then they sat down and started to examine what (...) they got.

Result so far: case closed. The investigation has not found and does not expect to find any irregularities beyond the scope of the negligible details. (...) 
In addition to me personally, an attempt was made to criminalize the entire library as well (with absolutely hilarious arguments), which similarly failed. The investigation specifically stated that the library is non-profit and does not generate income. (...) Sometimes a banana is just a banana ${ }^{34}$.

This apparently positive news was met with contrasting reactions from the members of the forum. Most of them expressed their joy, hoping that this would set a precedent that would allow illegal libraries to emerge from the shadows. Others advised not to relax or lose vigilance and emphasized the "stress" of being exposed to an investigation. Some users teased Stiver, inviting him to reveal his identity since he is already known to the police. However, users finally agreed on the usefulness of remaining anonymous in order to avoid trouble. Notably, international precedents for the arrest of individuals responsible for shadow libraries, such as the Pirate Bay founders in 2010, were not mentioned in the discussion, even though the Pirate Bay case had been previously debated in the forum.

The investigation on "Stiver" did not set a precedent in Russia: a German court resolution did not change either the Russian authorities' relations towards the library nor its perception by Russian publishing houses. However, this led to a strong imperative to remain anonymous. The site's "rules" section makes clear the crucial importance of anonymity, stating that "actions intended or likely to endanger the security or personal rights of users are prohibited. In particular, impersonation is prohibited ${ }^{35}$ ". When I requested an in-person interview with Flibusta's other principal administrator, "Roger", he categorically refused any means of communication that could potentially lead back to him, referring me back to the trial "Stiver" had endured.

Finally, the third task to be accomplished in order to guarantee the durability of the collections is to ensure access to them. Roskomsvoboda tried to set a judicial precedent for

\footnotetext{
${ }^{34}$ https://flibusta.is/node/261839, accessed 15 September 2020.

35 http://flibusta.is/node/4023, accessed 15 September 2020.
} 
preventing blockages to shadow libraries during the first lawsuit of that kind: the trial against Rutracker, one of the biggest Russian stream aggregators, in November 2015. After the court decided for the "eternal" blocking of this resource, Roskomsvoboda's lawyers launched a campaign for the abolition of such restrictive measures. Roskomsvoboda has called this campaign "The battle for Runet", thus placing free access to cultural content in the category of digital freedoms, together with other types of resistance to censorship. A website was set up to collect funds and signatures ${ }^{36}$, and a complaint signed by seven thousand people was submitted to the court. Their argument was that "restricting access to the entire site due to a few items from the catalogue of Eksmo Publishing violates the rights of millions of site users to access content on the site and the rights of thousands of authors who voluntarily distribute their works to the Rutracker audience" ${ }^{37}$. This attempt to turn the affair into a political struggle did not bear fruit: this claim was dismissed twice and did not affect the further proceedings.

In a context of increasingly frequent blockages from 2015 onwards, it was necessary for shadow libraries to nonetheless find a way to make resources visible to the wider public. The first way consisted of multiplying "mirrors" in locations that are considered safe. For example, the .lib domain, ruled by Emercoin, is regarded as such thanks to its decentralized structure. In its current form, the Domain Name System root is under the centralized authority of Internet Corporation for Assigned Names and Numbers (ICANN, a Los Angeles-based nonprofit). In this system, every DNS record is kept by the DNS provider and can be blocked under political or commercial pressure; however, "in a decentralized DNS each record is managed solely by its owner, and is readable by all users on the network" 38 . Networks that guarantee anonymity, like Tor and "Invisible Internet Project" (i2p), are also suitable to

\footnotetext{
${ }^{36} \mathrm{https}$ ://zarunet.org/, accessed 5 September 2020.

${ }^{37} \mathrm{https}$ ://roskomsvoboda.org/18866/, accessed 5 September 2020.

38 https://roskomsvoboda.org/12118/, accessed 5 September 2020.
} 
escape national constraints, which leads shadow libraries to have their "representatives" there ${ }^{39}$.

The second way focused on instructing users. Since the beginning of site blockages, libraries and forums have displayed lists of the technical means to escape the communication barriers created by Russian Internet service providers at Roskomnadzor's request. This dissemination of circumvention knowledge seems to be omnipresent and circulates through many additional channels: mailings ${ }^{40}$, posts on social networks and explanations on Youtube. Roskomsvoboda has also organized masterclasses and disseminated lists of circumvention strategies $^{41}$. The proposed solutions include the change of DNS server, browsers with turbo mode (Opera, Chrome, and Yandex) ${ }^{42}$ or embedded VPN, special plug-ins for browsers, VPN services, Tor browser and the use of anonymizers. These lists are often illustrated with pictures and tutorial videos ${ }^{43}$. Community members who are (or were in the past) programmers explain to non-technical users how each method works, present its advantages and disadvantages (which are usually speed of execution versus simplicity of use). They also monitor specific tools and then share the results of their observations with other users by advising them on a particular VPN or anonymizer. This mastering of circumvention tools today becomes a part of the know-how of every person visiting the shadow libraries.

In addition to the torrents mentioned above, library users and administrators compete in creativity to organize the distribution of new archive updates. Here again, the proliferation of means and media is the rule. For example, Librusec.ucoz, a forum common to several

\footnotetext{
${ }^{39}$ https://roskomsvoboda.org/28612/, accessed 5 September 2020.

40 https://www.securitylab.ru/news/489269.php, accessed 5 September 2020.

${ }^{41}$ https://openrunet.org/, accessed 5 September 2020.

42 Invented by the developers of the Opera browser in 2009, the turbo mode was intended to increase browsing speed: data is first downloaded to the browser's server, and the user downloads it from where in compressed form. But the fact that the data transits through Opera's server allows this tool to be used for bypassing site blockades: the ISP cannot detect and therefore deny access to banned sites.

${ }^{43}$ See, for instance, https://booktracker.org/viewtopic.php?t=79239, accessed 30 September 2020.
} 
shadow libraries and which acts as a safe harbour in case the internal forum is inaccessible, has a section called "Our Tortuga" 44 . One of the administrators of the forum puts there the links to the updates of Librusek and Flibusta databases via free file-sharing sites.

In parallel to these external but friendly sites, the communities use social networks and messaging. For example, a bot on the Russian social media VKontakte allowed, for a while, to make a quick search in the shadow libraries and thus facilitate access in case of breakdown or blocking ${ }^{45}$. However, in June 2019, VKontakte and the publishing house Eksmo concluded a settlement according to which the social network has to check the legal status of all the books downloaded by users. However, this did not lead to the disappearance of the bot: in September, it was transferred to a safer storage medium ${ }^{46}$.

After the tightening of VKontakte's attitude towards illegal content, some shadow libraries began to actively use Telegram bots to distribute books, as this messenger was known to be tolerant to illegal content thanks to the libertarian worldview of its owner, Pavel Durov. However, by August 2020, these bots would have stopped working, supposedly as a result of an agreement between Telegram and the Russian authorities. While announcing the news on the Flibusta forum, the users immediately suggested a technical solution to bypass this new barrier:

Flibusta bot has been blocked not only on iOS, but also on android.

How to make the bot work again? It is simple - you need to do the following steps:

1. Create a group;

2. Add a bot to it by clicking on the following link (...). ${ }^{47}$

\footnotetext{
${ }^{44} \mathrm{http} / / /$ ibrusec.ucoz.de/forum/7-171-318\#105370, accessed 16 July 2020.

${ }^{45}$ See Flibusta's VK page: https://vk.com/wall-98093156 238, accessed 2 September 2020.

${ }^{46}$ See https://github.com/FlyInk13/FlibustaBot, accessed accessed 5 September 2020.

${ }^{47}$ http://flibusta.is/node/474924, accessed 5 September 2020.
} 
By adding the bot to a group, the system would therefore stop considering it as such. Thus, users leverage the internal shortcomings of the messaging system to bypass blockages.

To summarize, the survival of libraries and the communities that sustain them is influenced by the multiplication of media and preservation sites, the responsiveness of the members of this community to the obstacles that arise as well as their ability to share tips and find creative technical solutions and to teach these techniques as widely as possible. The communities that animate shadow libraries leverage the technical know-how of their members to help make these libraries perennial and elusive. The permanence of communication channels seems essential in this process, hence their multiplication and sometimes their redundancy.

This is likely part of a wider dynamic. According to Keucheyan and Tessier, in today's digital world, the idea of a "revolution" does not seem very promising in the light of the counter-revolutions it would entail; thus, hackers do not seek confrontation. Rather, "they take advantage of the interstices, disperse and reform elsewhere" (Keucheyan and Tessier, 2008, p.457). But if, according to the authors, these symbolic diversions can only take place in a democratic country, we have shown how they also find their way in authoritarian contexts. Russian NGOs fighting for open access, such as Association of Internet Publishers, Wikimedia.ru or Roskomsvoboda, are part of international networks and endorse globalized political struggles. Shadow libraries stand aside and promote a conception of "freedom" that goes beyond politics, anchored in the mastery of technical tools and cultural practices that are not censored by an authority outside their community.

\section{Conclusion}

In Russia, the struggles for an Internet free of censorship and those for open and fair access to literary texts overlap to some extent. On the one hand, digital rights defenders are 
indeed mobilizing for both causes, encompassing them under the same label of "free Internet". On the other hand, the organizations fighting against these shadow libraries, whether at the service of the state (Roskomnadzor) or that of the Russian book industry (ASAPI), conceptualize "pirates" in the same way as "extremists" or "child pornographers", whom they have to censor: the idea is then to "purge" the Runet of these dangerous and impure elements, supposedly linked to the darknet and foreign organizations, to banish them from the Russian online public space. Outside Russia, this has led to a gradual politicization of shadow libraries administrators: having started as "merry men happily sharing what was sold", they found themselves in the same struggle as "victims of persecution and political censorship" which gave them a "cause for rebellion" (Bodó, 2015, p. 7). This politicization of the communities around Russian mass-literature shadow libraries has not yet been detected: concentrating on the technical aspects of circumventing constraints and training users, they keep away from public protest actions, conducted on their behalf by organisations defending digital freedoms. For example, the few explicitly "political" posts on anti-copyright mobilizations around the world hardly provoke any reaction, unlike the posts on technical issues which are widely discussed. However, these communities do cultivate an irony and a folklore that reflects their detachment from, and sometimes even aggressive rejection of, the copyright industry and its profit values.

These communities hold a special place in the nebula of "hackers". They overcome legal and technical boundaries to disseminate copyright protected content, and technical expertise goes hand in hand with the literary knowledge that is their raison d'être. Russia presents a rich breeding ground for the symbiosis of love of books and technical mastery, since the technical intelligentsia, known for its infatuation with reading, strongly invested the Internet. Yet, the majority of Russian hackers are confronted, above all, with foreign industries. Thus, the so-called "carders" have mainly devoted themselves to stealing 
American credit cards, sometimes paralleling their acts with a patriotic anti-American discourse (Turovsky, 2019). Shadow libraries carrying audio or video content were primarily in conflict with US copyright industries (Kiryia, 2011). Russian academic shadow archives, like LibGen and SciHub (Bodó, 2018), challenge the Western academic publishing system that generates inequalities in access to knowledge (Karaganis, 2018). Unlike them, literary text archives focus on Russian language texts (originals or translations), and therefore interfere very little with foreign actors. Facing the Russian book industry presents additional challenges. Its majors constitute a foundation for the legitimate culture of the supposedly "most-reading nation", a cliché inherited from the Soviet Union that the current government wishes to promote as a marker of a specific identity. This explains the state's support for this industry and the weight of this sector in the elaboration of the new legislation against the illicit distribution of cultural production.

Communities with changing contours, promoting the idea of "absolute freedom" attached to the pirate imaginary, unintentionally disrupt the enterprise of creating a sovereign "pure" Runet allegedly containing a national legally approved literature, and thus contribute to develop and disseminate circumvention techniques.

\author{
About the Author \\ Bella Ostromooukhova is Associate Professor of Russian Language and Culture at Sorbonne \\ Université. Her research focuses on sociological aspects of independent book-publishing in \\ contemporary Russia. \\ Email: ostrob [at] gmail.com
}




\section{References}

Anastasija Alekseeva, Ivan Zasurskij et al, eds., 2013. Transformacija Avtorskogo Prava v Internete. Zarubezhnye tendencii, biznes-modeli, rekomendacii dlja Rossii (Copyright Transformation on the Internet. Foreign trends, business models, recommendations for Russia), Moscow: Associacija internet-izdatelej.

“Antipiratskij zakon, pravoprimenenie, tendencii I sistemnye problemy za period 08.201306.20172017” (“Antipiracy law: application, trends and systemic problems for the period 08.2013-06.2017’'), at https://antipiracy.changecopyright.ru/, accessed 15 June 2020. Baptiste Bacot and Clément Canonne, 2019. "Musique et hacking: de l'éthique aux pratiques," Volume!, volume 16, issue 1, pp. 7-14.

John P. Barlow, 1996. "A Declaration of the Independence of Cyberspace” (https://projects.eff.org/ barlow/Declaration-Final.html, accessed 15 September 2020. Balázs Bodó, 2018. “The Genesis of the Library Genesis: The Birth of a Global Scholarly Shadow Labrary", In: Joe Karaganis (ed). Shadow libraries. Boston: MIT Press, pp. 25-51. Balázs Bodó, 2015. “The common paths of piracy and samizdat”. In: V. Parisi (Ed.), Samizdat. Budapest: CEU Institute for Advanced Study, pp. 19-34.

Gabriella Coleman, 2013. Coding Freedom: The Ethics and Aesthetics of Hacking. Princeton, Oxford: Princeton University Press.

Eric Dagiral, 2008. "Pirates, Hackers, Hacktivistes: Déplacements et dilution de la frontière électronique", Critique, number 733-734, pp. 480-495.

Primavera De Filippi and Mélanie Dulong de Rosnay, 2014. « Le pirate informatique, un explorateur des courants juridiques du réseau », Tracés. Revue de Sciences humaines [Online], volume 26, pp. 43-65 
Ronald Deibert and Rafal Rohozinski, 2010. "Control and subversion in Russian cyberspace" in Ronald Deibert et al. (eds.), Access Controlled. The Shaping of Power, Rights, and Rule in Cyberspace, Cambridge, MA and London: MIT Press, pp. 15-34.

Michiel Elst, 2005. Copyright, Freedom of Speech, and Cultural Policy in the Russian Federation, Law in Eastern Europe, Leiden: Brill.

Bill Herman, 2012. “A political history of DRM and related copyright debates, 1987-2012”, Yale Journal of Law and Technology, number 14.1, pp.162-225.

Samuel Hayat and Camille Paloque-Bergès, 2014. «Transgressions pirates », Tracés. Revue de Sciences humaines, number 26, pp. 7-19.

Vladimir Haritonov, 2016. Elektronnoe knigoizdanie v Rossii. Problema dostupa $i$ gosudarstvennoe regulirovanie (Electronic book publishing in Russia. The problem of access and state regulation.). Moscow, Associacija internet-izdatelej

Ramzmig Keucheyan and Laurent Tessier, 2008. " Présentation. De la piraterie au piratage », Critique, volume 733-734, number 6, pp. 451-57.

Joe Karaganis, 2018. "Introduction: Access from Above, Access from Below”, in Joe Karaganis (ed.), Shadow Libraries, The MIT Press. Boston: The MIT Press, pp. 1-24.

Razmig Keucheyan, 2008. «Philosophie politique du pirate », Critique, n $733-734$, p. 458469.

Ilya Kirya, 2011. "Le piratage audiovisuel en Russie post-soviétique, entre logiques économiques et culturelles", in Tristan Mattelart (ed.), Piratages audiovisuels, De Boeck Supérieur. pp. $239-255$.

Ilya Kiriya and Elena Sherstoboeva, 2015. "Russian Media Piracy in the Context of Censoring Practices", International Journal of Communication, Vol. 9, pp. 839-851. 
“Knizhnyj rynok Rossii. Sostojanie, tendencii i perspektivy razvitija. Otraslevoj doklad” (“Russian book market. Status, trends and prospects for development. Industry report”), 2020. Moscow: Federal'noe agentstvo po pechati i massovym kommunikacijam.

Miroslav Kruk, 1999. "The internet and the revival of the myth of the universal library", The Australian Library Journal, 137-147, number 48:2, pp. 137-47.

Lawrence Lessig, 2006. Code: version 2.0. New York: Basic Books.

Stefania Milan, 2017. "Data Activism as the New Frontier of Media Activism", in Media Activism in the Digital Age, edited by Goubin Yang and Viktor Pickard, Routledge.

Evgeny Morozov, 2012. The net delusion: The dark side of internet freedom. New York: PublicAffairs.

Jakub Nowak, March 2016. 'The Good, the Bad, and the Commons: A Critical Review of Popular Discourse on Piracy and Power, During Anti-ACTA Protests', Journal of ComputerMediated Communication, 21.2, pp.177-194

Bella Ostromooukhova, June 2019. “Négocier le contrôle, promouvoir la lecture. Éditeurs indépendants face à l'État dans la Russie des années 2010”, Bibliodiversity.

Il'ja Rassolov, 2016. Pravo i kiberneticheskoe prostranstvo (Law and cyberspace). Moscow: Moskovskoe bjuro po pravam cheloveka.

Pamela Samuelson, 2003. "Copyright and Freedom of Expression in Historical Perspective”, Journal of Intellectual Property Law, number 10, p. 319.

Tat'jana Savickaja, 2011. “Iz istorii komp'juternogo andergraunda: jepoha BBS i Fidoneta (chast' 2)" (“A history of the computer underground: the BBS and Fidonet era (part 2)"), Kul'tura v sovremennom mire, number 3/2011.

Andrej Soldatov and Irina Borogan, 2016. Bitva za Runet. Kak vlast' manipuliruet informaciej i sledit za kazhdym iz nas (Battle for Runet. How the authorities manipulate information and watch all of us). Moscow: Al'pina. 
Valeria D. Stelmakh, 2001. "Reading in the Context of Censorship in the Soviet Union", Libraries \& Culture, number 36, issue 1, pp. 143-51.

Anne-Marie Thiesse and Natalia Chmatko, 1999. « Les nouveaux éditeurs russes », Actes de la recherche en sciences sociales, volume 126-127, March, pp. 75-89.

Zeynep Tufekci, 2016. "As The Pirates Become CEOs: the closing of the Open Internet”, Daedalus, pp. 65-78.

Fred Turner, 2006. From counterculture to cyberculture: Stewart Brand, the Whole Earth Network, and the rise of digital utopianism. Chicago: University of Chicago Press.

Turovskij, Daniil, 2019. Vtorzhenie. Kratkaja istorija russkih hakerov (Invasion. A brief history of Russian hackers). Moscow: Individuum.

Jeroen Van Laer and Peter Van Aelst, 2010. "Internet and social movement action repertoires: Opportunities and limitations". Information, Communication \& Society, number 13(8), pp. 1146-1171.

Joel Waldfogel, 2018. Digital Renaissance: What Data and Economics Tell Us about the Future of Popular Culture. Princeton and Oxford: Princeton University Press.

Olga Zaslavskaya, 2015. "Samizdat. Between Practices and Representations". Lecture series at Open Society Archives, Budapest, February-June 2013. IAS Publications no. 1. Budapest, Central European University, Institute of Advanced Study, pp. 87-99.

Ivan Zasurskij, 2016. Novaja Model' Regulirovanija Avtorskih Prav. Obshhestvennoe Dostojanie i Koncepcija Obshhego Blaga (A new model of copyright regulation. The public domain and the concept of the commons). Moscow: Associacija internet-izdatelej. 